\section{KUITURA \\ i}

$\begin{array}{llllllllllllllll}\text { F } & \text { A } & \text { K } & \text { T } & \text { Y } & & \text { I } & & \text { P } & \text { R } & \text { O } & \text { B } & \text { L } & \text { E } & \text { M } & \text { Y }\end{array}$

IRENEUSZ KRZEMIŃSKI

Uniwersytet Warszawski

\title{
STEFAN NOWAK. ODWAGA I PERSWAZJA, CZYLI SOCJOLOGIA W CZASACH IDEOLOGICZNEJ OPRESJI
}

Niedawno, 6 września 2009 r., minęła dwudziesta rocznica śmierci Stefana Nowaka, wybitnego polskiego socjologa, wieloletniego przewodniczącego i współtwórcy Polskiego Towarzystwa Socjologicznego, które zawiązało się po październiku 1956 r. Więcej — uczonego, który miał ogromny wpływ na kształt naukowej socjologii w Polsce popaździernikowej, jeśli dalej używać tej znaczącej cezury w naszych powojennych dziejach. Jego wpływ polegał na tym, że propagowana przez Stefana Nowaka metodologia badań socjologicznych, zwłaszcza ankietowych, stała się obowiązującym standardem akademickim, który znacząco ograniczył czysto ideologiczny język i partyjne wpływy w nauce, przynajmniej w jej badawczej aktywności. Wymogi warsztatowej rzetelności w socjologicznej empirii stały się znaczącym czynnikiem przeciwdziałania ideologicznej, pseudonaukowej samowoli. To jedna $z$ wielkich zasług Stefana Nowaka, od razu dodam, że mego profesora i nauczyciela, człowieka, który mnie i moich kolegów ze stworzonej przez siebie gromadki darzył przyjaźnią i otaczał opieka, co było szczególnie doniosłe w ponurych latach PRL, gdy niektórych $z$ nas dotykały restrykcje bądź dotkliwe kary, wymierzane przez partię-państwo.

Zapewne też z okazji tej rocznicy Antoni Sułek, bodaj najstarszy żyjący z tej gromadki uczniów, przygotował wybór tekstów Stefana Nowaka O Polsce i Polakach $^{1}$. Zebrane teksty są prawdziwie socjologicznymi rozprawami i studiami różnych zagadnień, dotyczą — jak lubił mówić i pisać Stefan Nowak — postaw i wartości polskiego społeczeństwa. Wiele $z$ nich to artykuły publikowane w ty-

Adres do korespondencji: krzemire@is.uw.edu.pl; Instytut Socjologii UW, ul. Karowa 18, 01-927 Warszawa.

1 Stefan Nowak, O Polsce i Polakach. Prace rozproszone 1958-1989, zebrał Antoni Sułek, Wydawnictwa Uniwersytetu Warszawskiego, Warszawa 2009, stron 376. 
godnikach społeczno-kulturalnych. Część to raporty i analizy z lat osiemdziesiątych. Wiele nigdy nie ukazało się w żadnym powszechnie dostępnym wydawnictwie, były publikowane $\mathrm{w}$ pracach drukowanych na prawach rękopisu w stu egzemplarzach, poza peerelowską cenzurą. Do dziś znaleźć tam można wiele inspirujących analiz. Chciałbym tu podzielić się refleksją nad lekturą prac Stefana Nowaka, lekturą przypadającą na czas szczególny: dwudziestolecia wolnej i niepodległej Rzeczypospolitej Polskiej. Drugiego w dziejach Polaków symbolicznego „dwudziestolecia”, wyznaczającego nam jakże odmienne perspektywy w porównaniu z tym „pierwszym”, zwanym międzywojennym.

\section{ODWAGA MYŚLENIA I NAUKA ZAANGAŻOWANA}

Stefan Nowak i jego naukowa socjologia mają swój wkład w dzieło wolności. I to wkład dwojaki: ściśle naukowy, o czym po części wspomniałem, ale też społeczny. Chodzi mi o to, że w latach sześćdziesiątych, a już zwłaszcza siedemdziesiątych, Stefan Nowak był swoistą instytucją naukową. Wspomniałem o jego roli w Polskim Towarzystwie Socjologicznym, jednym $z$ tych, nielicznych, które nieustannie były na „partyjnym indeksie”. Ale również chodzi o jego rolę na Uniwersytecie, gdzie był ostoją naukowej rzetelności, lecz także swobody myślenia i badania, a również jasności reguł i zasad. Ich bazą było zawsze przywiązanie do ideałów wolności i demokracji, najgłębsza niechęć do uznania reguł ideologicznych, pętających myślenie i życie. Był symbolem odwagi myślenia i mówienia prawdy o świecie, nigdy nie można było mu zarzucić konformizmu wobec partii-państwa i ich ideologii, jak wielu, bardzo wielu uczonym, skądinąd dla nauki i potem dla wolności zasłużonym. Nabył niezwyczajnej umiejętności układania się z władzą, z systemem partii-państwa, ale zawsze z pozycji aktora niezależnego. Do dziś myślę z wielkim podziwem o tej postawie $i$ tej umiejętności Stefana Nowaka. Dla obserwatorów był to zawsze znak odwagi.

W moim odczuciu Stefan Nowak zawsze był liberałem, który całą swoją postawą prezentował zasady niezależności i samodzielności, prawa do własnych przekonań i sądów, do wyboru tego, co uznaje jednostka za wartościowe i słuszne, a także - człowieka nieskłonnego do podległości i nastawionego nie na narzucanie swego zdania innym, lecz na dyskusję z użyciem argumentów. Debata i dyskusja mieściły się w samym jądrze nauki. W dyskusji Stefan Nowak był niedościgniony i jego talent wymyślania argumentów na poparcie czasem nawet ryzykownych tez nie miał równego sobie. Myślenie teoretyczne było zawsze starciem racji i argumentów. Wiązało się z tym przekonanie, że trzeba brać odpowiedzialność za swe czyny i w konsekwencji człowiek powinien przede wszystkim liczyć na siebie, na własne wysiłki i własną pracę. Kiedy zagłębiłem się w lekturze tekstów mojego mistrza, znalazłem zaskakujące potwierdzenie takiego jego obrazu.

Mówię, że było to zaskakujące potwierdzenie osobistych odczuć, bo za życia Stefana Nowaka z częścią kolegów z naszej „gromadki” prowadziliśmy z nim 
namiętne dyskusje na temat nauki i niedostatków pozytywistycznego jej modelu. Jako uczony metodolog nasz mistrz był zwolennikiem modelu nauki ścisłej, badającej świat społeczny ,jak rzeczy”, nauki odwołującej się do ścisłych pomiarów i obliczeń, a więc nauki, która miała być niezaangażowana $\mathrm{w}$ aktualne oceny w życiu społecznym. Kiedy jednak czyta się dzisiaj teksty, które powstały między rokiem 1959 a 1989 - a więc w jakże zmieniającym się czasie historycznym! — uderza ich zaangażowany charakter. Nawet wtedy kiedy $\mathrm{w}$ gazetowych artykułach pojawiają się pierwsze w historii tabelki z wynikami analiz korelacyjnych, to służą one do przekonywania i dają wiedzę, która ma służyć ludziom: zarówno ówczesnej władzy, jak i społeczeństwu. Wspominałem o wielkim talencie Nowaka do dyskutowania i przekonywania. W jego tekstach ten duch przejawia się w całej pełni. Stefan Nowak używa wiedzy empirycznej, wiedzy zgromadzonej w rzetelnych badaniach do tego, aby przekonać czytelników do... ano, właśnie, do czego? Najpierw zawsze do znaczenia prawdy, nawet tej cząstkowej prawdy o postawach i poglądach ludzi, jaką dają badania socjologiczne. Lepiej wiedzieć naprawdę, co myśli i jak czuje społeczeństwo, żeby móc nim rządzić sprawnie i rozumnie - to do władzy. Ale podobnie perswaduje Stefan Nowak „zwykłym ludziom”, że mają prawo i myśleć, i czuć, i także działać zgodnie ze swymi przemyśleniami i wartościami i starać się nawet w ograniczonych warunkach chcieć i „coś robić”: „Sądzimy, że należy indywidualnie i zbiorowo przeciwstawić się poczuciu, iż «nic zrobić nie można». To, że ktoś czuje się sfrustrowany blokadą swych prywatnych czy publicznych dążeń, może tłumaczyć wiele jego zachowań [...], ale nie musi ich usprawiedliwiać" (s. 280). Perswazja zawarta w pracach Stefana Nowaka zawsze była wezwaniem do działania, przekonywaniem, że nawet w tych „wiemy, jak trudnych warunkach" człowiek, zarówno jako jednostka, jak i jako członek społecznej wspólnoty, nie powinien popadać w marazm, wycofywać się z życiowej aktywności. Tym bardziej, jeśli uda się zaakceptować podstawowe, deklarowane wartości „socjalistycznego sytemu”.

Uderzające jest to, że „prawdziwa nauka”, która wedle filozofii pozytywistycznej miała być oderwana od wartości, w tym przypadku raczej wartościom służyła, nic nie tracąc ze swej wyrafinowanej metodologii. Najwyraźniej dla Stefana Nowaka rozumienie nauki było w praktyce bardziej zgodne ze znacznie starszą tradycją filozoficzną niż deklarowany przezeń pozytywizm: nauka była szukaniem prawdy, ale zarazem i stanowieniem dobra. Naukowe obliczenia i publikowane tabelki $z$ wynikami badań zawsze służyły do przekonania czytelników jego tekstów o czymś ważnym.

\section{SOCJALIZM STEFANA NOWAKA I LIBERALIZM „NAUKOWY”}

Gdy czytałem wstęp moich kolegów, stanowiący przedruk artykułu napisanego tuż po śmierci Nowaka, nieufny byłem wobec ich tezy o głębokim przywiązaniu Stefana do „socjalizmu”. Gdy jednak dobiegłem końca lektury książki, 
trudno mi nie przyznać im racji. Teza o społecznej akceptacji przynajmniej „podstaw socjalizmu”, jak i inna, która głosiła „umiarkowany egalitaryzm” jako stałą cechę polskiej mentalności, była istotnie czymś znacznie więcej niż opisem stanu społeczeństwa. Tezy te stanowiły ważny element systemu przekonań Stefana, były zatem czymś więcej niż tylko „grą z systemem”. Bo Nowak toczył swoją walkę, pojęciową "grę z systemem”, z oficjalnym, ideologicznym i politycznym sensem słowa „socjalizm” - coś, co potem na masową skalę powtórzyło się w ruchu „Solidarności”. Trudno teraz odtworzyć socjalistyczne przekonania Nowaka, bo nie można pominąć tej „gry z systemem” i oficjalnym językiem PRL-u jako sprawy ważnej. Głównie była to chęć przekonania ówczesnych partyjnych władców Polski, że nie powinni traktować ludzi jak wrogów, bo większość z nich akceptuje hasła socjalizmu. Nieco mniej oczywiste było to, że niekoniecznie chodzi o socjalizm w wydaniu sowieckim, zaadaptowany do warunków polskich. Ale o tym, że studenci Warszawy najczęściej opowiadali się za socjalizmem „jak w Szwecji”, tego w artykułach w „Nowej Kulturze”, czy „Przeglądzie Kulturalnym” już nie przeczytamy. Bo przecież chodziło o to, aby w ogóle móc opublikować te artykuły, pisane ze współpracownikami (Zofią Józefowicz i Anną Pawełczyńska).

Gdy dziś czyta się tamte teksty, wydaje się, że Stefan Nowak pozostawał w głębokiej zgodzie $z$ obrazem społeczeństwa, jaki tworzył i do którego był przywiązany. Byłby to, zapewne, ten socjalizm, który w jakiś sposób został zaadaptowany i wchłonięty przez demokratyczny system europejski. Składałaby się nań zasada sprawiedliwości, pewien stopień regulacji i kontroli gospodarki przez państwo, ale już nie egalitaryzm, co najwyżej „umiarkowany egalitaryzm", który nie neguje zróżnicowania dochodów w zgodzie z wykształceniem, ważnością pełnionej roli, odpowiedzialnością za wykonywaną pracę, ale który też chciałby ograniczenia nadmiernej rozpiętości dochodów i warunków życia obywateli. Często powtarza się w rozważaniach Nowaka zwłaszcza zasada równości szans, przy jednoczesnym łagodzeniu przez państwo nierówności i konfliktów społecznych. Ciekawe jest zagadnienie gospodarki: wydaje się, że autorowi badań raczej podobało się to, że znacząca część badanych Polaków (np. robotników Warszawy w połowie lat osiemdziesiątych) chciała zachować państwową własność najważniejszych gałęzi przemysłu ciężkiego, jak to się mówiło w języku realnego socjalizmu, a resztę gospodarki poddać kontroli rynkowej i prywatnej własności.

We wszystkich wnioskach z badań chodziło o to, aby sens „socjalizmu” $z$ ideologicznego słownika władzy poszerzyć, wzbogacić o treści, które ze zdogmatyzowanymi założeniami ideologii marksizmu-leninizmu mniej lub bardziej się kłóciły - a w każdym razie traktowane były przez przedstawicieli władzy partii-państwa $z$ dużą nieufnością. Najogólniej chodziło o to, aby pojęcie socjalizmu zbliżyć do tego sensu politycznego, jaki miało ono w niekomunistycznym ruchu socjalistycznym, co oznaczało nade wszystko uznanie demokracji i chronionych przez nią swobód obywatelskich za właściwy ustrój państwowy. 
„Socjalizm z ludzką twarzą” — hasło polskiego Października '56 — to socjalizm bez dyktatury i przemocy, co - jak wiadomo - okazało się postulatem, który nie zyskał uznania w kręgach władzy: był zbyt trudnym wyzwaniem dla partii-państwa, zanurzonego w sowieckim systemie. Ale dążenie, aby dyktaturę i wszechobecną kontrolę nad obywatelami ograniczyć - to był zasadniczy kierunek społecznych i intelektualnych wysiłków polskiej inteligencji, zresztą tak silny, tak poważnie wypełniający codzienność i odświętność, że prowadził do zaskakująco dobrych efektów. Stefan Nowak z całą pewnością był na pierwszej linii boju o to, aby „ucywilizować” totalitarny koszmar PRL-u, aby też pokazać rządzącym - i tym na samej górze, i może jeszcze bardziej tym na średnich szczeblach - że opłaca im się dla skuteczności władania i efektywności zarządzania, w tym także gospodarczego, poluźnić pęta albo zgoła zdjąć je z ludzi, stworzyć choćby ograniczone kanały możliwości spontanicznego, twórczego działania.

I tutaj otwiera się pytanie o wspominany już wcześniej „liberalizm” Nowaka. W zaskakujący sposób łączył się on z przekonaniami - nazwijmy to tak - demokratycznego socjalizmu. Ta dziwna zbitka przekonań ideologicznych była, zapewne, efektem zakochania się Stefana w Ameryce. Nie ulega wątpliwości, że ogromna część jego przekonań społecznych dałaby się łatwo pogodzić z przekonaniami amerykańskich demokratów. W tym sensie można pogodzić „socjalizm" z ,liberalizmem": wszak demokraci amerykańscy wyznają idee, które często określa się mianem „amerykańskiego socjalizmu”. To, co niezwykle ważne dla tych przekonań, to głęboki antykolektywizm, odróżniający znacząco Amerykę od Europy. Ludzie, jednostki, konkretne osoby są podstawowymi elementami budującymi „społeczeństwo”. To aktywność indywidualna, chęć podjęcia działania i wzięcia przez jednostki odpowiedzialności za świat, w którym żyją, jest całkowicie niezbędnym warunkiem działania społecznego. Akcent na odpowiedzialność człowieka za jego losy, konieczność aktywnej postawy, samodzielność i brak roszczeń wobec innych i wobec państwa - tworzyły rodzaj prawdziwie „liberalnej postawy” samego Nowaka.

Moi koledzy - Mirosława Grabowska i Antoni Sułek — wskazują we wstępie na to, że Nowak lekceważył wszystko to, co było "ponadjednostkowe”. Sądzę, że i tutaj chodziło o pewną liberalną wizję społeczeństwa, w którym „struktury" nie są osobnymi bytami, lecz powstają jako efekt działań ludzkich, że to, co „społeczne”, da się sprowadzić i wyjaśnić jako efekt cech jednostek i sieci stworzonych przez nie stosunków, zależności, interakcji. Sens zasad, reguł, norm — w tym także moralnych — zawarty jest koniec końców w ludzkich sercach i umysłach, dlatego też badanie postaw i przekonań ludzi stało się dla Nowaka podstawową zasadą naukowego badania świata.

Naukowość tego „indywidualizmu”, jak mówią moi koledzy, wynikała i była uzasadniona stanowiskiem metodologicznym Stefana Nowaka. Nie były to przekonania ideologiczne, bo sądzę, że ideologii obawiał się on najbardziej ze wszystkiego. Niechęć do uznawania realności bytów ponadjednostkowych 
w dużym, ogromnym stopniu brała się z tej niechęci do ideologii, zamykającej świat w jednoznacznych, uporządkowanych normach i mówiącej o bytach kierujących się „swoimi prawami”, jak choćby marksistowskie Prawa Historii. Wszakże w refleksji metodologii nauk społecznych od lat trzydziestych aż - bodaj - do lat sześćdziesiątych niezwykle ważny był konflikt między jak to się określało - indywidualizmem a kolektywizmem metodologicznym. Jedni twierdzili, że to jednostki są podstawowymi elementami społeczeństwa, drudzy zakładali ontologiczne, a przynajmniej — jak to formułowano - epistemologiczne istnienie „całości społecznych”, których własności są nieredukowalne do cech ludzi oraz ich wzajemnych relacji. Antyindywidualiści uważali, że pojawiają się „,cechy emergentne”, których w żaden sposób nie można sprowadzić do poziomu cech indywidualnych ani też - do efektu relacji między jednostkami. W tym sporze naukowym Stefan Nowak na pewno był po stronie „indywidualistów”, a przed zarzutami chciałbym go bronić o tyle, o ile Stefan Nowak zawsze uwzględniał, przynajmniej teoretycznie, element relacji i sieci zależności między ludźmi jako coś, co obok indywidualnych cech jednostek pozwala na efektywne wyjaśnienie zjawisk społecznych, także tych „makro”. Nie znosi to faktu, że z całą pewnością Nowak należał do naukowego obozu indywidualistów metodologicznych - ale trudno czynić mu $z$ tego zarzut, zwłaszcza uwzględniając kontekst polski, czy raczej — kontekst totalitarnego komunizmu, zakładający kolektywizm, nie tylko ograniczający indywidualną ekspresję człowieka, ale czyniący jednostkę wytworem w pełni społecznym, historycznym.

\section{RELIGIA}

Obrona jednostki jako niezależnego „elementu świata” jest także jednym z głównych powodów, dla których Stefan Nowak jak lew bronił swego prawa do bycia agnostykiem, jak to określał w czasie naszych burzliwych dyskusji w ponurych latach stanu wojennego. Wtedy gdy całe młodsze pokolenie inteligencji uznało wartość religii i zanurzyło się w życie kościelne, nie zawsze, jak wiadomo, tylko religijne, ale także społeczne i kulturalne, trudno było nie toczyć takich debat. Bez względu na wyrozumiałość i chęć zrozumienia tego nowego nastawienia inteligencji nawróconej na wiarę nie chciał uznać żadnej zwierzchności nad myśleniem, nad umysłem, nawet Pana Boga samego. W dyskusjach z nami, młodszymi, nawet coraz bardziej dostrzegając znaczenie religii, bronił swego prawa, żeby pozostać przy pytaniu o istnienie Boga i nie odpowiadać na nie inaczej, jak „nie wiem”. Z całą pewnością było to związane z tradycją socjalistyczną obecną w mentalności Nowaka.

Od początku do końca, od wielkich badań nad studentami Warszawy aż po jeden $z$ ostatnich artykułów, sprawa religijności odgrywa znaczącą rolę $\mathrm{w}$ jego rozważaniach i analizach. Trudno się oprzeć refleksji, że jest tu podobnie jak w kwestii socjalizmu: obraz społeczeństwa, jaki odczytuje badacz, ulokowany 
jest $\mathrm{w}$ sieci bardzo osobistych przekonań. Jak to zwykle bywało w popaździernikowych latach pięćdziesiątych, po części w sześćdziesiątych, a przede wszystkim w „epoce gierkowskiej”, część tych obrazów społeczeństwa i przekonań autora miała charakter perswazji wobec władzy. Część jednak z nich była obecna od badań studenckich aż po ostatnie teksty o religijności. Jedną z pierwszych i najważniejszych konstatacji była teza o względnej niezależności przekonań religijnych od poglądów społeczno-politycznych. Tak to się Stefanowi Nowakowi układało w jego wynikach badań nad studentami Warszawy i ważność tej tezy potwierdzał także $\mathrm{w}$ roku 1987. Co prawda, została ona znacząco zmodyfikowana, ale Nowak nie chciał uznać tego, co dla większości socjologów w latach osiemdziesiątych było oczywiste: Kościół katolicki stał się aktywnym aktorem, wyrazicielem postaw, poglądów, aspiracji ogromnej części Polaków, w tym także przekonań religijnych i wartości religijnych. Wiara i typ religijności wówczas w kościele obecny i przez Kościół wyrażany stanowiły istotne umocnienie wielu zasadniczych przekonań społeczno-politycznych, takich choćby jak godnościowy charakter akceptacji praw człowieka i obywatela. W tekście z 1987 r. bardzo dobrze widać chęć zróżnicowania postaw społecznych i twierdzeniom przyznającym pozytywną rolę Kościołowi (i religijności) zaraz towarzyszą spostrzeżenia, iż występują również inne postawy. O procentowych przykładach nie ma jednak mowy, bo przecież w praktyce były one bardzo nikłe.

Tutaj perswazyjność Stefana Nowaka służyła raczej wyrażeniu przezeń obaw związanych $z$ tak całkowitą akceptacją Kościoła i powszechnością deklaracji religijnych. Być może z perspektywy czasu można powiedzieć, że kryjące się za tym obawy nie były bezpodstawne, ale obraz, którego wówczas Stefan bronił, nie całkiem przystawał do rzeczywistości polskich postaw.

Religijnych identyfikacji i Kościoła jako punktu odniesienia Polaków nie ma również w najbardziej znanym w Polsce i na świecie obrazie polskiej mentalności, jaki stworzył Stefan Nowak (Polaków portret wtasny, w bardziej „naukowej” wersji System wartości społeczeństwa polskiego, także tekst publikowany po angielsku Values and attitudes of Polish people). Obraz ten mówił o „próżni społecznej”, bo opisywał więzi i identyfikacje Polaków jako obecne i intensywne na najniższym, rodzinno-przyjacielskim poziomie, a później — ważne i mocne od razu na poziomie narodu. Nie było tego, co niekiedy socjologie nazywają więziami $\mathrm{i}$ instytucjami średniego zasięgu. W tej diagnozie kryła się troska, a także dochodził do głosu — jak sądzę — raczej liberalizm niż socjalizm Stefana Nowaka. Właśnie liberalna wizja społeczeństwa pozwala przypisać szczególne znaczenie rozbudowie sfery organizacji społecznych, stowarzyszeń, instytucji o węższym i szerszym zasięgu pośredniczących między postawami i interesami jednostek i rodzin a poziomem narodowym i państwowym.

W obrazie Stefana Nowaka, i to stworzonym w końcu lat siedemdziesiątych, nie istniały w ogóle więzi religijne ani identyfikacje z Kościołem. A przecież pisał to wówczas, gdy znaczenie Kościoła jako wyraziciela postaw, wartości 
i aspiracji społecznych dla nikogo nie ulegało wątpliwości. Stefan jakby obawiał się przypisać Kościołowi i - ogólnie - religijności Polaków istotne znaczenie w procesie dążenia do wolności i demokracji. Jakby wolał wciąż pamiętać o wynikach badań nad studentami, które dawały dowód, że: „Kościół i religia nie były wówczas postrzegane w kategoriach politycznych czy społeczno-ustrojowych" (s. 287).

Zapewne, kryły się za takim stosunkiem do Kościoła i religijności obawy uczonego, by wiara nie stała się orężem politycznym i nie służyła do spętania swobody myślenia. W tekście z 1987 r. Stefan szczególnie mocno akcentował te wyniki badań z przeszłości, które dowodziły tolerancji Polaków wobec przekonań religijnych i światopoglądowych. Tu ujawniła się owa „perswazyjność” jego wywodów, obecna również w przypominaniu danych, które pokazywały, że znacząca część niewierzących to nie byli marksiści, nie należeli więc wcale do przeciwstawnego katolickiej religijności obozu ideowego. Nie każdy niewierzący to zarazem wróg religii. Gdy zaś konkludował, zgodnie z wynikami wszelkich badań $z$ lat osiemdziesiątych nad postawami i wartościami Polaków, że stosunek do religii przestał być — jak to było po Październiku '56 — sprawą „prywatnej filozofii Polaków”, to zarazem znajdował wszelkie dane, które miały pokazać, że: „Kościół nie jest w Polsce «instytucją integrująca wierzących w zwartą grupę społeczną [...]». Jest on raczej postrzegany jako instytucja zaspokajająca osobiste potrzeby katolików. Nie jest natomiast podkreślam - grupą" (s. 300). Trudno powstrzymać się tutaj od konstatacji, że na ten obraz świata społecznego miały wpływ wartości i postawy uczonego: nade wszystko dochodziła tu do głosu obawa przed zjednoczeniem katolików w zwartą grupę, która mogła zagrozić podstawowym swobodom obywatelskim i ludzkim, o które przecież chodziło. Można to odczytać jako jeszcze jeden znak „liberalizmu” Stefana Nowaka.

\section{NAUKA I WARTOŚCI}

Powraca zatem jak bumerang problem prawdy naukowej i pytanie o to, jak dalece badanie socjologiczne i opis jego rezultatów może i powinien być oddzielony od wszelkich wartości. Wszak metodologia Stefana Nowaka zakładała to w bardzo wysokim stopniu. Lektura jego dzieła wskazuje jednak na coś istotnego dla naukowego obrazu świata, zwłaszcza takiego obrazu, w którym wyciąga się wnioski z pomiarów i tabelek, pragnie się mówić ludziom o ich wspólnym życiu coś ważnego. Wnioski i uogólnienia niosące znaczące przesłanie o świecie nie mogą nie być zakorzenione w świecie wartości. „Czysta empiria" wcale nie przemawia do nas, jeżeli to, co z bezstronnej obserwacji wynika, nie jest odniesione do społecznych czy kulturowych standardów oceniania i rozumienia świata. Stefan Nowak nienawidził ideologii i bał się religii jako możliwego, bezwzględnego regulatora poglądów i przekonań ludzkich, zabierającego niezależność myślenia i swobodę badania rzeczywistości. 
Ale dlatego też jego obraz postaw ludzkich, wartości i dążeń był i jest tak znaczący. Sam zresztą pisał w podręczniku metodologii, iż badacze różnią się sposobem interpretacji danych: jedni wolą poprzestać na suchej analizie, inni, o większym temperamencie badawczym, chcą formułować dalekosiężne uogólnienia. Autor tych słów z całą pewnością niesiony był wspaniałym badawczym temperamentem, ale przez to wizja „nauki bez wartości” całkiem nie pasuje do dzieła, które pozostawił.

Dlatego aksjologiczne i uogólniające odniesienia tez Stefana Nowaka pozostają dalej inspirujące. Ot, choćby teza o braku powiązań ponadrodzinno-przyjacielskich nabrała na nowo znaczenia w niepodległej i demokratycznej Polsce, której obywatele wciąż cierpią na niechęć do tego, by się stowarzyszać i zawiązywać organizacje formalne. Tezę tę krytykowałem już wcześniej, bo — jeśli byłaby prawdziwa - to bardzo trudno byłoby wyjaśnić i opisać socjologicznie powstanie NSZZ „Solidarność”. Podkreślam fakt, że ruch społeczny „Solidarności” powstał i rozwinął się wokół budowania organizacji związkowych, które w całej rozciągłości były właśnie owymi wypełniającymi „próżnię społeczną” instytucjami „średniego zasięgu”, pośredniczącymi między poziomem jednostek i rodzin a państwem i narodem. Obraz Nowaka nie tylko nie zawierał więzi kościelnych, ale też $\mathrm{w}$ ogóle ignorował poziom identyfikacji i także nieformalnego grupowania się ludzi w ich miejscach pracy. Ale gdyby nie było pośredniczących więzi między grupkami rodzinno-przyjacielskimi, to jak mógłby zawiązać się wielomilionowy związek zawodowy w tak zawrotnym tempie?

Obraz Nowaka jednak i dziś może być inspirujący, bo być może to, co on sam nazwał „najniższym poziomem” organizacji więzi i identyfikacji ludzi, wcale nie jest tak płaskie, ale kręgi rodzinno-przyjacielskie i koleżeńsko-rodzinne rozrastają się w złożone, znacznie „wyższe” więzi lokalne, terytorialne i środowiskowe. Wyraziłem kiedyś tezę, że „próżnię społeczną” Stefana Nowaka wypełniały takie twory jak choćby silne więzi pokoleniowe, które niekiedy obejmowały znaczne obszary kraju i wiele kręgów lokalnych. Nie były to kręgi sformalizowane, ale żyjące podobnymi wartościami - by użyć ulubionego pojęcia Nowaka - i dążące do wspólnych celów, a przede wszystkim chętne do współpracy ze sobą. Być może do diagnozy Stefana Nowaka warto wrócić, dodając do niej zupełnie nowy aspekt, tym razem całkiem odbiegający od liberalnych oczekiwań socjologicznych: społeczeństwo może rozwijać więzi i wspólnotę działania oraz realizować różne swoje cele i aspiracje wcale nie formując organizacji formalnych. Pozostając na poziomie nieformalnych powiązań ludzie mogą skutecznie działać dla osiągnięcia różnych celów, czy to lokalnych, czy to w grupie zawodowej, czy to w inaczej jeszcze wyodrębnionych, ponadjednostkowych i ponadrodzinnych kręgach.

Z obrazem społeczeństwa przywiązanego do „socjalizmu” w ogóle trudno się $\mathrm{w}$ tej chwili zgodzić, bez względu na to jak był on prawdziwy — być może - dla studentów Warszawy w końcu lat pięćdziesiątych i w latach sześćdzie- 
siątych. Stefan Nowak nie zauważył jednak tych momentów, które stanowiły także symboliczne punkty zwrotne w oddalaniu się Polaków od socjalizmu. Tutaj nasuwa się ciekawa obserwacja Antoniego Sułka: Stefan Nowak nie był obecny w Polsce i nie mógł osobiście doświadczyć kilku niezwykle ważnych wydarzeń. Mimo głębokiego związku z ideami Października '56, wtedy gdy odbył się choćby słynny wiec na placu Defilad w Warszawie, gdy między innymi domagano się uwolnienia kardynała Wyszyńskiego, dając akceptację Gomółce - był za granicą. Podobnie, gdy wiec studentów Uniwersytetu Warszawskiego 8 marca 1968 r. stał się początkiem antysemickiej nagonki partii-państwa, ale jednocześnie momentem uformowania się pokolenia, które niosło zupełnie nowe idee aktywności społecznej - Stefan Nowak był w Stanach Zjednoczonych. Powraca tu więc w jeszcze inny sposób zagadnienie metodologii nauki: nie tylko chodzi o to, że badacz, który nie dzieli doświadczeń społecznych, może nie dostrzegać wagi pewnych zjawisk i procesów, które - zwłaszcza w takich warunkach, jakie były w PRL - mogą być ukryte, ale też chodzi o to, że być może narzędzie badawcze, w które tak wierzył Stefan Nowak, nie zawsze dostarcza wystarczająco głębokiej wiedzy o świecie społecznym i ludziach. Metoda ankietowa była bowiem jego zasadniczą metodą naukowej socjologii i orężem $\mathrm{w}$ walce $\mathrm{z}$ ideologicznym zakłamaniem. Ale metoda ankietowa przy całych swych wielkich zaletach - ma też wady, które ograniczają punkt widzenia badacza.

Jeszcze o jednym warto wspomnieć: o wielkim zainteresowaniu Stefana Nowaka problematyką młodzieży i jej akcentowaniu w jego obrazie świata społecznego Polaków. Najważniejsze badania dotyczyły młodzieży: zarówno badania studenckie, jak i wielki projekt lat siedemdziesiątych, czyli badania nad konfliktem pokoleń. Wiara w siłę i świeżość młodzieżowych postaw i działań nabierała charakteru stereotypu socjologicznego, nic więc dziwnego, że także ruch „Solidarności” interpretował on jako „ruch przede wszystkim młodych”. Ba, wcale nie było to prawdą, bo nie najmłodsi, nie ci, którzy stanowili rdzeń kategorii „młodzieży”, byli drożdżami tworzenia Niezależnego Samorządnego Związku Zawodowego. Faktem jest jednak, że gdy nastał stan wojenny, tak zbrodniczy wobec społecznych i narodowych dążeń, to najmłodsi Polacy uformowali kolejne pokolenie, wojujące o wolność i swobody obywatelskie.

Dla najmłodszych Polaków i także dla młodszego pokolenia socjologów teksty Stefana Nowaka, zamieszczone zresztą w chronologicznym porządku, pod jeszcze jednym względem stanowią niezwykle ciekawe świadectwo czasów PRL. Uderzająca jest różnica języka, stopień otwartości wywodów i rozwinięcia myśli między tekstami z końca lat pięćdziesiątych i tymi z lat osiemdziesiątych. Brzmi to trochę jak paradoks, bo przecież w ponurych latach osiemdziesiątych mieliśmy do czynienia z koncentracją władzy, z jawną, codzienną represją za „podziemną" i niezależną działalność, także za niezależne myślenie. Mimo to bardzo dobrze widać, zwłaszcza na tle wcześniejszych tekstów, jak swobodny był już wtedy język, jak aluzje i wieloznaczność stwierdzeń zastąpił klarowny 
wywód i jednoznaczność wyrażanych i sugerowanych wniosków. Dla socjologów to bardzo ciekawe świadectwo, wskazujące, jak bardzo PRL zmienił się między rokiem 1958 a 1988. Czas PRL, pomimo zachowania podstawowych instytucji, na czele $z$ urzędem cenzury i służbami specjalnymi, nie był wcale jednolity. Przemiana języka i sposobu wyrażania myśli, prezentowania wyników badań, wyciąganych wniosków, co można zaobserwować w tekstach Stefana Nowaka, jest znacząca. Pierwsze teksty, mimo całej odwagi głoszenia niezależnych poglądów i pomysłowych zabiegów perswazyjnych, noszą znamiona czegoś, co trzeba nazwać autocenzurą: czuwającą świadomością piszącego, aby poddawać dokładnej kontroli to, co się pisze, tak by mogło przejść przez sita instytucjonalnej cenzury. Teksty zamykające książkę, choć część z nich była publikowana, niemal wcale nie mają tej cechy. Przemiana języka jest też znakiem przemiany postawy piszącego uczonego. Ale ta przemiana tylko dokumentuje ogromną przemianę w społeczeństwie $\mathrm{i}$ - państwie. Można to uznać za znaczący dowód na to, że generał Jaruzelski mimo wojskowych rządów nie mógł nie skapitulować przed społeczeństwem. Twórczość Stefana Nowaka i jego życiowa aktywność $\mathrm{w}$ nauce i $\mathrm{w}$ życiu społecznym wpisuje się $\mathrm{w}$ to wielkie dzieło wyzwalania się Polaków. Jego praca była częścią narodowego dążenia do wolności. 